\title{
The Idea of Tragedy in Arthur Miller's The Crucible and A View from the Bridge
}

\author{
Hanyue $\mathrm{Li}^{1}$ \\ ${ }^{1}$ School of English Studies, Shanghai International Studies University, Shanghai, China \\ Correspondence: Hanyue Li, School of English Studies, Shanghai International Studies University, Shanghai, \\ China.
}

Received: April 30, 2018 Accepted: May 17, 2018 Online Published: May 24, 2018

doi:10.5539/ells.v8n2p115 URL: https://doi.org/10.5539/ells.v8n2p115

\begin{abstract}
Arthur Miller is acknowledged as a heavyweight in portraying ordinary life's tragedy in twentieth-century America. He believes that tragedy is no longer confined to the kingly man placed aloofness from others; he denies rigid definitions of traditional Greek tragedy and enriches them to keep abreast of the times in modern society. Most Miller scholars, unfortunately, are still preoccupying themselves with Death of a Salesman. Available criticism of these two plays is scant and not extensive. This paper studies both the ostensible structures of standardized Greek tragedy and the hidden ideas of modern tragedy as they are intertwiningly applied to the two texts to see how Miller expresses his idea of modern tragedy behind the shield of Greek tragedy and how it gives a new lease on the life of antiquated classical tragedy in modern society.
\end{abstract}

Keywords: Greek tragedy, modern tragedy, The Crucible, A View from the Bridge

\section{Introduction}

At the outset of the twentieth century, man is seen as a victim of his surroundings and society is thought to have become a shaping force in men's lives. The classical tragic mode is archaic and it no longer suits for ordinary life in modern society. Increasingly, scores of dramatists become preoccupied with social and political issues. Under such circumstances, Arthur Miller attempts to remold the classical concept of tragedy and formulates an acceptable modern definition of tragedy. Even if he denies some major principles found in standardized Greek tragedy, one cannot ignore that Greek tragedy has an indelible impact on Miller's works. The Crucible and A View from the Bridge display characteristics of both Greek Tragedy and Miller's idea of modern tragedy. This paper attempts to draw on certain theories of Greek Tragedy and Miller's conception of modern tragedy which are the foundations for the subsequent analysis. Then it respectively analyzes how distinctive characteristics of Greek Tragedy feature these two plays including the functions of the role of chorus which consists of an implicit narrator in The Crucible and an explicit narrator in A View from the Bridge, the tragic hero, the tragic flaw and catharsis, attempting to perceive Miller's underlying ideas of modern tragedy.

\section{Greek Tragedy and Arthur Miller's Modern Tragedy}

Greek tragedy has its beginnings in choral performances, in which a group of men sing hymns and dance in praise of god Dionysus throughout the play. The function of the tragic chorus, both as a real and ideal entity, is to comment on the dramatic actions and draw universal ethical conclusions from the play. The tragic chorus is called time and time again to participate affectively in the actions by voicing the feelings which the play evokes, to summarize information that facilitates the audience's understanding of the play, to comment on the actions by revealing moral implications and social significance (Bushnell, 2005, p. 215-233). At the same time, the chorus members provide time for scene changes and give the protagonists a break; they offer important background information and allow for the tragic plot to unfold. As the importance of the characters increases, the tragic chorus become fewer in number and tends to have less importance in the plot. Modern realist tragedies no longer feature a choric role as Greek Tragedy does in Oedipus Rex.

Another important element in Greek Tragedy that has played a dominant role is the role of tragic hero. The standardized tragic hero is a noble and honorable man with a tragic flaw which eventually leads to his destruction. He must be greatly superior; he must possess a great reputation and good fortune. The tragic hero should be defined by a hierarchical order and his demise is the result of his fatal flaw, his own fault which others 
cannot be blamed for. Aristotle stresses that the hero's downfall from such height should have a public significance. His tragic downfall brings about strong emotions of fear and pity among the audience. The catharsis is an emotional relief through which the audience can achieve a state of moral and spiritual renewal and obtain a sense of liberation from stress and anxiety after they undergo emotions of fear and pity. Aristotle believes that the function of tragedy is to arouse this catharsis - a purging of emotions and a release of tension. Golden also points out that what is accompanied by tragedy is not merely pity and fear, but the representation of pitiful and fearful situations, a clarification of such incidents (Golden, 1962, p. 51-60). These particular fearful and pitiful events so skillfully arranged and presented by the playwright lead the audience to the cathartic effect and perceive a universal condition of human existence.

As a practical playwright, Miller blends social, political, moral and personal questions presented directly and indirectly through the characters in most pieces of his works, revealing social injustice and its effect on the lives of his characters in modern society. His concept of tragedy is deeply grounded in his concerns with social problems. In his essay Tragedy and the Common Man, he presents his conception of tragedy. Tragedy, he writes, is the consequence of a man's total compulsion to evaluate himself justly. Tragedy derives from the underlying fear of being displaced and being torn away from our chosen image of who we are (Roudane, 2015, p. 8). Miller focuses on the internal conflict between the individual and society. For the most part in his essay, he sees the tragedy inherent in the situation as a consequence of the failure of the individual's struggle against the society he lives in. Man should not be conceived of as a private entity and his social relations as something attached to him, but rather he must be seen as constantly in the process of becoming part of the society which also simultaneously shapes him.

His idea of tragedy aforementioned to some extent subverts the Aristotelian tragedy in that Aristotelian tragedy derives from a fatal tragic flaw which leads to a hero's crisis and downfall while Miller's tragedy comes from the external forces operated on the man, his failure of confrontation towards the society he lives in. The importance of the tragic flaw is diminished in Miller's viewpoint. Insofar as he regards external factors as the source of tragedy, he argues common man is apt for tragedy as kings are. Miller argues for the impossibility of tragedy if tragedy must be about the socially elevated nobles in the social hierarchy, because the modern age is an age without rigid hierarchy which is eliminated by democracy. He argues for the possibility of a common tragic hero by observing the fact that modern psychiatry deals with such conceptions as the Oedipus complex which can be applied to anyone no matter whether he is a king or a common man (Roudane, 2015, p. 9). He makes it clear that the common man experiences the same mental processes as the high-born heroes of the past, facilitating the secularization of tragedy. Tragedy, furthermore, is not exclusively about individuals, but more precisely about humanity and it reveals the truth about human societies. Miller explores themes of a personal search for forgiveness and salvation. The individual's tragedy lies deep down not only in his psychology as well as the tragic flaw, but in his milieu which is influenced by the socio-economic system. Man's own personality, psychology and social and moral forces act upon each other and bring about the individual's end.

In his essay The Nature of Tragedy, Miller stresses the distinction between pathos and tragedy. Pathos merely arouses feelings of sympathy, sadness, and possibly identification. Tragedy, however, brings the audience fear besides sadness, sympathy and identification; it also brings knowledge and enlightenment (Roudane, 2015, p. 12). For Miller, knowledge is ethical knowledge, the right way of living in the world. His idea of tragedy related to ethical knowledge here can be viewed as an equivalent to the catharsis in Greek Tragedy which stresses the audience's moral enlightenment after the undergoing of fear and pity. Miller further points out that tragedy is inseparable from a certain hope regarding to humans. The glimpse of hope inherent in tragedy can function to raise sadness out of the pathetic towards the tragic, which adds a hint of optimism in modern tragedy.

\section{The Idea of Tragedy in The Crucible}

Miller begins to adapt the device of chorus from the classical Greek Tragedy when creating The Crucible, and in his next play A View from the Bridge he also uses the choric role to unfold the tragedy. He employs an implicit omniscient narrator, a parallel of Greek chorus, to address the audience to tell the story. Not being part of the action, the implicit narrator provides detailed information on the characters and comments on the social background of the play. He traces the history of the characters to show that the long-held hatred of neighbors who turn on each other has its historical origins. The constant bickering over land boundaries can cause the citizen's grievance and resentfulness which eventually leads one to take revenge on the other. The neighbors' pent-up dissatisfaction towards one another provides excuses for their later invented accusation of witchcraft in the dramatic text. Some people are accused of witchcraft by others who merely feel envy and hostility towards them, revealing the guise of morality in Salem. Except for the disclosing of the steeped-in tradition of vengeance in his detailed monologue, he also introduces the history of Salem in which people's way of life is extremely 
strict and somber. In Salem, the inhabitants oppose individuality for they see it as a threat to their existing social order. The community is intolerant of individual thinkers who question or refuse to accept what they are told to believe (Ackerman, 2013, p. 115). The dominant ideology is held by the religious authority that runs the government and manipulates the citizens. Judge Hawthorne and Reverend Parris, therefore, have chance to abuse their power, and characters like Abigail could manipulate it to her selfish advantage. These background issues of land ownership, personal vengeance and power struggles give ample evidence to the tumult of Salem where it is overtaken by accusations of witchcraft. The concern with social problems, social injustice and its effect on the lives of the characters is evident in Miller's plays. The choric narrator uses the lengthy background information to foreshadow Proctor and others' tragedies, and accounts for the inevitability of their tragedies in morally degenerate Salem. Miller applies a choric role to weave in and out of the characters' dialogue and at the same time comments on the milieu of the play, which illustrates the historical parallel between the witch hunt in Salem in 1692 and McCarthyism in the current United States and reflects that tragedies are socially determined.

The Crucible has the outline structure of Greek Tragedy with Proctor as a standardized tragic hero. Procter is an upright, reasonable and honest man, but he has an affair with Abigail, which is a fatal flaw that leads him to death. Their affair plays a significant role - an incident that touches off the widespread fear of witchcraft throughout the play. Elizabeth, Proctor's wife, dismisses Abigail after she spots their affair, resulting in Abigail's vengeance - the indictment of witchcraft—on her. Abigail's revenge on Elizabeth never seems more than a way of removing Elizabeth and marrying Proctor. Not only does Abigail accuse Elizabeth of witchcraft, but she also sets the witchcraft hysteria in motion in Salem. She starts to accuse the community's outcasts and gradually moves up to the respected members of the community, which causes community-wide fear of being indicted of witchcraft. Proctor initially tries to hide their affair, but later he realizes that nothing can prevent Abigail's instigation but his confession to their affair. He eventually admits their affair and his guilt publicly, coming to save his threatened wife and defend something more than his wife. His tragic flaw results in his downfall, but his role of a tragic hero shows a larger view of Miller's conception of modern tragedy. Asked to concede a lie of participating in the witchcraft, he refuses to sign the document admitting the false confession. When Judge Danforth demands an explanation, Proctor cries out "because how may I live without my name? I have given you my soul; leave me my name!" (Miller, 2015, p. 328). He refuses to provide a false confession under the threat of his impending death. Miller stresses that tragedy is evoked when the tragic hero is ready to lay down his life to secure his personal dignity because he is embroiled in the social mire. Faced with the trumped-up charge, Proctor would rather go to the gallows than give false testimony. He saves his sense of himself, his dignity as a man; he seeks the meaning of his own life when threatened by the invented charge.

His tragedy is also intensified by the fault of the society according to Miller's idea of modern tragedy. Judge Hawthorne and Deputy Governor Danforth believe that they are emissaries of God and everything they do must be right. Having realized that they might be deceived by Abigail and other girls, they never reassess their actions because they think the citizens in the community would target at them if they knew the judges had made impaired judgement. Parris also knows this but he makes scapegoats of people including Proctor and Rebecca in order to strengthen his position as the Reverend of Salem. They connive at hateful revenge under the shield of righteousness. The church abuses their immense power, resulting in the innocents' tragedies. Thus the importance of the tragic flaw as a disadvantage in Proctor's character diminishes, and the tragedy stems from the corrupted stifling social environment. As Miller deeply believed, individual tragedies do have their social roots. Man's tragedy is viewed as constantly in the process of being shaped and inevitably influenced by the environment which he lives in. Miller's focus on social problems not only expresses the characters' tragedies, but reflects the moral truth concerning society. Miller's concept of modern tragedy does have ethic values; there exists no tragedy without messages of moral values. The death of the innocents as scapegoats in the historical corrupted society shows a larger impending tragedy in American society, McCarthyism.

In classical Greek Tragedy, the downfall of the tragic hero arouses strong emotions of pity and fear. The audience sympathizes with his misfortune and feels pity for his inevitable fate. At the conclusion of The Crucible when Proctor sacrifices his life to retain his sense of integrity with the intoning of the final prayer, the audience feels something more than pity and fear. Miller writes, "There lies within the dramatic form the ultimate possibility of raising the truth-consciousness of mankind to a level of such intensity as to transform those who observe it" (Miller, 1956, p. 36). He strongly believes that the tragedy can lead the audience to ponder something bigger such as ethic and moral problems closely interrelated with humans; he also believes in the capability of the audience to achieve spiritual enlightenment from tragedy. Proctor struggles to reconstruct a new self through which he is able to become worthy of respect from others and retrieve his name again. Not only does Proctor's death evoke great sympathy, but it impresses the audience with enlightenment and knowledge - the high 
consciousness of defending one's dignity when he is mired in dilemma. It provides the audience an insight into the importance of regaining one's integrity in the world. Miller also points out that there exists a glimpse of hope regarding humans in tragedies. This hint of hope inherent in tragedy is enough to raise sadness out of the pathetic towards the tragic. The audience can observe the optimism when Proctor stands up to defy the religious authority in order to preserve his integrity as a man. No matter how corrupted and unscrupulous the social environment has become, there are always upright people shining through in it.

\section{The Idea of Tragedy in $A$ View from the Bridge}

In $A$ View from the Bridge, the most conspicuous achievement in the light of Miller's exploration of Greek tragedy is the use of the form of a modified Greek chorus. Alfieri, equivalent to the chorus in classical Greek Tragedy, plays a vital role in the play. He functions as Eddie's friend in the intratextual level of communication, engaging with the characters in the play; he also plays a choric role of narrator in the extratextual level of communication, engaging with the audience outside the play. The two taken roles make him an impersonal omniscient narrator who opens and closes the play with a poetic monologue with an unbiased and unemotional view about the actions in the play. At the opening of the play, Alfieri functions as a choric role to offer important background information that facilitates the audience's understanding of the play. He sets the scene and unfolds the story in a flashback from his memories. He initially addresses to the audience that Italian-American immigrants of Red Hook not only essentially distrust the civilized American law, but tacitly regard their primitive Italian heritage as an infallible law, which reveals an imbalance of their American identities with their collective Sicilian heritage. Alfieri's explicit expression of this conflict between their allegiance to Sicilian customs and their denial of American laws foreshadows the inevitability of Eddie's death shortly afterwards. More significantly, it functions to reveal the nature of Eddie's tragedy.

Eddie has an incestuous love for his niece Catherine. He protects her from any male relations and has unconsciously taken her for his lover until the arrival of Rodolpho who has a crush on Catherine and becomes a threat to him. Rodolpho and Marco's arrival from the Old World ruins a sense of male dominance that Eddie hankers for both in his family and in the Brooklyn docks. He believes that Rodolpho has stolen Catherine from him, and therefore he goes to Alfieri's office to seek a legal way to prevent their wedding. Alfieri tells Eddie that there is nothing he can do in a legal action because Rodolpho has done nothing illegal. Driven by his primitive passionate love for his niece, Eddie breaks family loyalty which is highly valued in his immigrant community, and anonymously phones the Immigration Bureau disclosing Rodolpho and Marco's illegal immigration. Eddie's impulsive accusation, a betrayal both to his family and his neighborhood, directly results in Marco's hatred towards him and indirectly results in his own death afterwards. Eddie behaved wrongly, and yet he is the one who has obeyed the law. Just as Eddie feels that Rodolpho steals Catherine from him, so Marco feels that Eddie steals his chance for providing his children with food. Marco is also a symbol driven by primitive impulses, a product of the Old World. He believes that he has the right to take revenge for the sake of his family. He retaliates by murdering Eddie out of his belief in this primitive form of justice, which shows the inevitable value conflict between two cultures. Playing a role of chorus, Alfieri unfolds the tragic plot and reveals the conflicted feelings that the plot arouses in the characters such as Eddie and Marco. His narration at the opening is full of innuendoes, insinuating Eddie's ineluctable fate to death at the end. However, Miller goes beyond the influence of Greek convention of the chorus, and further reveals that tragedy lies in the external forces operated on man - the conflict between American identity and primitive heritage. The primary concern is no longer the inner crisis experienced by Eddie, but the external cultural conflict operating on him. Not only does Eddie's impulsive passion without any considerations for consequences throw him into a vicious conflict, but the conflict between two cultures makes him sink deeper and deeper into the mire of his tragedy.

The function of a chorus member also displays that Alfieri time and time again comments on the actions by revealing his moral implications. He knows what went before and what comes after. He perceives Eddie's tragedy as an exemplary incident and attempts to see some larger significance in his tragedy, as Welland in his book suggests. He assumes that "this play is 'a view from the bridge' not only because its setting is Brooklyn, but more importantly because it tries to show all sides of the situation from the detached eminence of the external observer. Alfieri is essential to the play because he is the bridge from which it is seen" (Welland, 1966, p. 105). Ostensibly, his position in the play is on the Brooklyn Bridge, which provides him a distant and panoramic stance to objectively observe the characters' actions and comment on their happenings in ethnic Brooklyn community. At a deeper level, he is able to see cosmopolitan and intellectual American culture represented by Manhattan and traditional Italian culture represented by ethnic communities in the Red Hook. Alfieri is a well-educated American lawyer of Italian ancestry. He respects American law and at the same time is loyal to Italian customs, symbolic of a linking bridge between American laws and communal principles. He 
metaphorically is meant to be a connection of modern American culture and ancient Italian culture, presenting greater social and moral implications in the work. In this postwar world, some lines between old and new worlds disappear, but cultural conflicts and imbalanced identities still linger on in the immigrant communities.

In Greek tragedy, when creating a tragic hero, the writer should observe two rules. First of all, the tragic hero must be good and noble. Secondly, he is the one typically with a fatal flaw as defined by Aristotle as Hamartia that ultimately leads to his own downfall. Eddie exactly fits into the example of a tragic hero. He is the breadwinner in his family and cares deeply about his wife and his niece. He is a larger-than-life figure; he is warm-hearted, honorable and well-respected in the docks, his work place, and Red Hook, the area where he lives. His incestuous feelings for his niece also play a crucial role of the tragic flaw in his character, leading directly to the tragedy of his death. Though his suffocating desire for possessing her has become central to him in his life, his reckless passion never makes its way into action in terms of their relationship. In his mind he is never more than a protective father-figure, willing to lay down his life to protect her even if, in others' eyes, such love is unnatural and has crossed the lines. In some senses his abstention from sexual relations with his wife is simply a result of his transference of affection to Catherine even if he subconsciously knows that he can never marry his niece. His subliminal obsession propels him towards his self-destruction. However, the tragic flaw, Miller writers, is not a weakness. "The flaw, or crack in the character, is really nothing and need be nothing but his inherent unwillingness to remain passive in the face of what he conceives to be a challenge to his dignity, his image of his rightful status. Only the passive, only those who accept their lot without active retaliation, are flawless (Roudane, 2015 , p. 8)". The widely accepted flaw as a shortcoming in the hero's character which precipitates his catastrophic action is transformed by Miller into what could seem to be a condition of his greatness, as Eddie and Proctor sacrifice their lives to secure their sense of self against the threat in A View from the Bridge and The Crucible.

In Greek tragedy, a tragic hero's fate is written before he is born. It is given by God and there is no escape. Such is the philosophy of the life of a tragic hero commonly accepted by critics as the guiding principle of Greek tragedy. In A View from the Bridge, during their two meetings, Alfieri has realized that the real problem of Eddie is his excessive unnatural love for Catherine. As Eddie's confidant, Alfieri realizes the direction in which Eddie is heading after his learning of the impossibility of the law to prevent Rodolpho and Catherine's wedding, but he is powerless to stop him. He endeavors to persuade Marco not to take revenge on Eddie and explains the limits of the law in America, but Marco insists that all the law is not in a book and Eddie would be dead now in his country. All Alfieri does to prevent the tragedy is to no avail. In Greek tragedy, the sense of fate resides for the most overwhelming part in forces outside of man. As with the case of Eddie, he is driven by an overwhelming force to destruction beyond the bound of reason.

However, fate is one force which is constantly driven by his sense of preserving his honor. One of Eddie's main concerns in the play is his honor and the respect he gets from others in his close-knit community. Eddie works hard to support his family and has a proud sense of honor. In the first act of the play, he is respected by his wife Beatrice and his niece Catherine in the family and well-liked by his friends in the neighborhood. But after the arrival of Marco and Rodolpho in his house, he feels that his respect is diminishing. He thinks that Rodolpho disrespects him by spending time with Catherine. Whenever Beatrice or Catherine disagree with him, he interprets it as a sign of disrespect. In addition, he is greatly concerned with his reputation amongst his neighbors. $\mathrm{He}$ is infuriated when Marco spits on him and accuses him of being a liar turning him in to the Immigration Bureau in front of the neighborhood. After his reputation is tarnished, his neighbors Lipari, Louis, and Mike ignore and ostracize him. In the end, having lost the respect of both his family and community, he refuses to leave his house and waits for Marco to apologize to him even if he knows what kind of consequences would follow after Marco sees him. In fact, he awaits an apology that clearly is not going to happen. Like so many other Miller characters, when he has drained his name of any meaning and betrays himself and others, he is ready to lay down his life to secure one thing - his sense of personal dignity. The more he is displaced from dignity, the more he attempts to seek to attain it. His tragedy is the consequence of his total compulsion to evaluate himself justly in his community when Marco destroys his fame. The underlying reason for his struggle is that of an individual attempting to gain his rightful position in society when his dignity is tarnished by others. Death is thus the only way he can resolve his dilemma, a situation of losing the love of his family, the respect of his community, his name and his identity as an Italian. Eddie has the wrong dream and wrong desires, and pays the ultimate price for having done so. Fatally illusioned, he inhabits a paradox he can never resolve; he is a common man who can do nothing to demand the world becomes what he expects it to be.

In $A$ View from the Bridge, desperate to salvage his reputation, Eddie calls Marco a liar when it is ironically he who is the real liar. Marco hits him and calls him an animal. Eddie pulls out a knife which is then turned against 
on him and Marco lunges at him. Eddie falls over and Catherine cries that she never meant to hurt him, showing love and sadness for Eddie in his dying moments. This, along with Alfieri's closing monologue, grants Eddie a measure of a positive reputation at the end of the play. Eddie resorts to the most extreme way-suicide with his own knife being turned against him - to dissolute self and to assuage his guilt. Eddie dies to restore his conscience he has breached twice over, once in his unacknowledged incestuous love for Catherine and once in his betrayal of his cousins. At any rate, Eddie has failed to know himself. He has failed as a member of his society or community, as a friend, neighbor, husband, guardian, and as a human being. But most importantly, he has failed himself and as a result he loses his identity. It is this moment of his recognition that creates great sympathy and fear among the audience. Eddie's death also calls an exalted kind of consciousness and an enlightenment as it makes the audience aware of what he might have been. He is a realistic modern hero in whom everybody can find himself. He evaluates himself justly, claims his whole due as a personality, and reaches beyond pathos towards the tragic. He never succumbs to his fate, and his struggle with himself and his misdirected sense of dignity lifts him above the banality of his life. His death is sort of a ransom from his sin, a struggle for achieving happiness and hope. Like John Proctor in The Crucible, Eddie at the last moment dies to preserve the meaning of dignity with which he wishes to invest his life, which achieves his inner coherence at least to himself. It arouses the audience's pity and creates a moral implication that he dies for his immortality and integrity.

\section{Conclusion}

It is generally assumed that a tragic playwright cannot thrive in the theatre of the populace and that tragedy is the archaic dramatic form which cannot be developed anymore in modern society. But Miller's successful creation of modern tragedies definitely proves it wrong. Miller insists on his modern conception of the nature of tragedy, but he never rejects classical tragedy wholesale (Bushnell, 2005, p. 202). Standing close to Greek Tragedy, both The Crucible and A View from the Bridge involve these characteristics of the classical tragedy including the choric role, the tragic hero, the fatal flaw and catharsis which promotes the understanding of the actual conflicted psychological process of tragic heroes in modern tragedies. Even though they could be viewed as contemporary equivalents to classical tragedies, they bear undeniable marks of modern tragedy. In his idea of modern tragedy, Miller gives his common man a tragic stature and offers him an opportunity to trade his life for greater significance when he is mired in guilt and helplessness. Miller goes beyond the social concerns with moral issues forced on tragic characters and further reveals the complex minds of tragic heroes struggling with guilt, dignity and hope. As this paper points out, under the screen of the form of Greek tragedy in these two plays, Miller intensifies the tragic quality, endows modern tragedies with significance, and gives a new lease on the life of tragedy in modern society.

\section{References}

Ackerman, A. (2013). A Student Handbook to the Plays of Arthur Miller: All My Sons, Death of a Salesman, The Crucible, A View from the Bridge, Broken Class. London: Bloomsbury.

Bushnell, R. (Ed.). (2005). A Companion to Tragedy. Oxford: Blackwell Publishing Ltd.

Epstein, A. D. (1965). A Look at a View from the Bridge. Texas Studies in Literature and Language, 7(1), $109-122$.

Golden, L. (1962). Catharsis. Transactions of the American Philological Association, 93, 51-60. https://doi.org/10.2307/283751

Horan, T. (2008). Another View from the Bridge. Arthur Miller Journal, 3(1), 17-28.

Miller, A. (1956). The Family in Modern Drama. Atlantic Monthly, 197, 36.

Miller, A. (2015). Miller Plays: One. Berkshire: Cox \& Wyman Ltd.

Palmer, D. (2012). Tragedy, Integrity, Guilt, and Shame: Understanding John Proctor. Arthur Miller Journal, $7(1-2), 23-41$

Roudane, M. (2015). The Collected essays of Arthur Miller. London: Bloomsbury.

Welland, D. (1966). Arthur Miller. New York: Oliver and Boyd Ltd.

\section{Copyrights}

Copyright for this article is retained by the author, with first publication rights granted to the journal.

This is an open-access article distributed under the terms and conditions of the Creative Commons Attribution license (http://creativecommons.org/licenses/by/4.0/). 